\title{
Comparative Study of the Antioxidant Activity of Holarrhena Floribunda and Picralima Nitida
}

\author{
Alida Edwige Odoh ${ }^{1, a, *}$, Désirée Mariette Yéhé2,b, Yao Kanga ${ }^{3, c}, G^{2}$ (ué-Noël Zirihi ${ }^{4, d}$, Diénéba Koné-Bamba ${ }^{1, e}$ \\ ${ }^{1}$ UFR of Pharmaceutical and Biological Sciences, Laboratory of Pharmacognosy, Botany, Plant Biology and Cryptogamy, Félix \\ HOUPHOUËT-BOIGNY University, 22 BP 714 Abidjan 22, Ivory Coast, Côte d'Ivoire \\ ${ }^{2} U F R$ of Pharmaceutical and Biological Sciences, Laboratory of analitical sciences and public health, Félix HOUPHOUËT-BOIGNY \\ University, 22 BP 714 Abidjan 22, Ivory Coast, Côte d'Ivoire \\ ${ }^{3}$ UFR of Biological Sciences, Department of plant physiology, Peleforo GON COULIBALY University, BP 1328 Korhogo, Ivory Coast, \\ Côte d'Ivoire \\ ${ }^{4}$ UFR of Biosciences, Laboratory of Biology and Health, University of Félix HOUPHOUET-BOIGNY, 22 BP 714 Abidjan 22, Ivory \\ Coast, Côte d'Ivoire \\ ${ }^{*}$ Corresponding author
}

\begin{tabular}{|c|c|}
\hline R T I C L E I N F C & B S T R A C T \\
\hline $\begin{array}{l}\text { Keywords: } \\
\text { Picralima nitida } \\
\text { Holarrhena floribunda } \\
\text { Antioxidant activity, } \\
\text { Côte d'Ivoire } \\
\text { Decoction }\end{array}$ & $\begin{array}{l}\text { Picralima nitida (Stapf) T.Durand \& H.Durand and Holarrhena floribunda (G.Don) T.Durand \& } \\
\text { Schinz are West and Central African plant species belonging to the Apocynaceae family. These two } \\
\text { plants are used in traditional Ivorian medicine to treat hypertension, urinary tract infections, } \\
\text { diarrhea, gonorrhea, malaria and diabetes. Phytochemical screening and evaluation of antioxidant } \\
\text { activity of } P \text {. nitida fruit and } H \text {. floribunda leaf extracts of each of these two species have already } \\
\text { been performed. In the present study, a comparative evaluation of the antioxidant activity of fruit } \\
(P \text {. nitida) and leaf }(H \text {. floribunda) decoctions was carried out. The decoctions of } P \text {. nitida fruits } \\
\text { and } H \text {. floribunda leaves were rich in secondary metabolites, especially polyphenols which have } \\
\text { good antioxidant activity. Quantification of total phenols and flavonoids gave respective values of } \\
\mathrm{QP}=15235.632 \pm 622 \mu \mathrm{g} \text { GAE / g dry matter and FP }=2.387 \pm 0.387 \% \text { for } P \text {. nitida and QH }= \\
68597.701 \pm 3171 \mu \mathrm{GAE} / \mathrm{g} \text { dry matter and FH }=17.581 \pm 0.379 \% \text { for } H \text {. floribunda. P. nitida } \\
\text { showed antioxidant activity against DPPH radical }(\mathrm{IC} 50=104.30 \pm 3.17 \mu \mathrm{g} / \mathrm{mL}) \text { and ferric ion } \\
\text { Fe3 }+(261.4 \pm 36.87 \mu \text { moL Eq Trolox / g extract). H. floribunda showed antioxidant activity } \\
\text { against DPPH radical }(\mathrm{IC} 50=41.73 \pm 0.29 \mu \mathrm{g} / \mathrm{mL}) \text { and ferric ion Fe } 3+(365 \pm 20.36 \mu \text { mol Eq } \\
\text { Trolox / g ExS). }\end{array}$ \\
\hline
\end{tabular}
Decoction $\quad$ Trolox / g ExS)

Keywords:
A B S T R A C T

Schinz are West and Central African plant species belonging to the Apocynaceae family. These two activity of $P$. nitida fruit and $H$. floribunda leaf extracts of each of these two species have already been performed. In the present study, a comparative evaluation of the antioxidant activity of fruit ( $P$. nitida) and leaf $(H$. floribunda) decoctions was carried out. The decoctions of $P$. nitida fruits good antioxidant activity. Quantification of total phenols and flavonoids gave respective values of $\mathrm{QP}=15235.632 \pm 622 \mu \mathrm{g} \mathrm{GAE} / \mathrm{g}$ dry matter and $\mathrm{FP}=2.387 \pm 0.387 \%$ for $P$. nitida and $\mathrm{QH}=$ $68597.701 \pm 3171 \mu \mathrm{g} \mathrm{GAE} / \mathrm{g}$ dry matter and $\mathrm{FH}=17.581 \pm 0.379 \%$ for $H$. floribunda. $P$. nitida edwigeodoh@yahoo.fr kanga.yao@yahoo.fr konebambadieneba@gmail.com

\section{(D) http://orcid.org/0000-0002-8930-3192 iD https://orcid.org/0000-0003-2132-180X \\ (i) https://orcid.org/0000-0003-4908-8667}

\section{d}

desireeyehe@gmail.com $\begin{array}{ll}\text { noel8zirihi@yahoo.fr } & \text { iD https://orcid.org/0000-0003-1558-0784 }\end{array}$

(c) (1) ) This work is licensed under Creative Commons Attribution 4.0 International License

\section{Introduction}

For many years, man has used various plant resources to satisfy his medical and food needs (Athamena, 2009; Sevindik et al., 2017). The Ivorian flora presents a great floristic diversity, in which medicinal plants occupy an important place. The originality of these plants lies in their capacity to produce very diverse active natural substances such as: carbohydrates, proteins, lipids and nucleic acids. In addition to these primary metabolites, plants provide secondary metabolites whose physiological function represents an important source of molecules that can be used in the fields of pharmacology and food (Macheix et al., 2005; Mohammed et al., 2018; Pehlivan et al., 2018). Much of the current scientific research interest focuses on the study of natural antioxidant molecules that act as free radical scavengers (Pan et al., 2008; Sevindik, 2021). These are highly reactive compounds with a single electron and are necessary for vital mechanisms. Antioxidant compounds, in addition to their importance in the treatment of certain pathologies, are also used for the preservation of edibles in the food industry (e.g., to prevent lipid oxidation) (Pan et al., 2008; Mohammed et al., 2019).

In addition, the consumption of a diet rich in antioxidants is associated with the prevention of many degenerative diseases in our modern societies characterized by stress, smoking, sedentary lifestyle and overeating. Increasing dietary intake of antioxidants will therefore have the primary objective of preventing these 
diseases (Koechlin, 2006; Mohammed et al., 2020; Mohammed et al., 2021).

In recent years, the commercial antioxidants used are synthetic antioxidants such as butylated hydroxyanisole (BHA), butylated hydroxytoluene (BHT), tertbutylhydroquinone (TBHQ) and propylgallate (PG). On the other hand, some authors have suspected that these molecules have some toxicity and could be responsible for liver damage and carcinogenesis (Pan et al., 2008; Atmani et al., 2009). Thus, we devoted our study to P. nitida and H. floribunda, two West and Central African plant species of potential antioxidant interest. The objective of the present study was to perform a comparative evaluation of the antioxidant activity of $P$. nitida fruit and $H$. floribunda leaf decoctions.

\section{Material and Methods}

\section{Materials}

\section{Plant material}

The plant material consisted of the fruits of $P$. nitida and the leaves of $H$. floribunda harvested in March 2019 in Agboville in Côte d'Ivoire.

The $P$. nitida sample was authenticated at the National Floristic Center of the Félix HOUPHOUËT-BOIGNY University of Abidjan. The herbarium was kept there under the name 1227 AKE ASSI.

The $H$. floribunda sample was authenticated at the National Floristic Center of Félix HOUPHOUËTBOIGNY University of Abidjan. The herbarium was kept there under the name 281B E. Adjanohoun. The leaves were taken and dried at room temperature for two weeks at the Laboratory of Pharmacognosy, Botany, Plant Biology and Cryptogamy of the Faculty of Pharmaceutical and Biological Sciences of the Félix HOUPHOUËT-BOIGNY University of Abidjan (UFHB). They were then crushed to obtain a fine powder.

\section{Equipment}

A mechanical grinder (RESCHT GM 300) was used for the extraction, a precision balance (Denver Instrument $\mathrm{Si}$ 602) for the weighing, a heating flask for the decoctions. For the study of the anti-free radical activity, a spectrophotometer (JENWAY 7315), was used.

\section{Methods} Nitida

Preparation of the Fruits Decoction of Picralima

$600 \mathrm{~g}$ of fruits were introduced into $1000 \mathrm{~mL}$ of distilled water $(\mathrm{m} / \mathrm{v})$. The mixture was boiled at $100^{\circ} \mathrm{C}$ for 15 minutes. After cooling, the homogenate was filtered through whattman $n^{\circ} 1$ paper and placed in an oven at $50^{\circ} \mathrm{C}$ until a dry extract of weight Pn was obtained.

Preparation of the leaves decoction of Holarrhena floribunda

$10 \mathrm{~g}$ of powder from the leaves of $H$. floribunda were introduced into $100 \mathrm{~mL}$ of distilled water $(\mathrm{m} / \mathrm{V})$. The mixture was boiled at $100^{\circ} \mathrm{C}$ for $15 \mathrm{~min}$. After cooling, the solution was filtered through whattman No. 1 paper and the resulting filtrate was the leaves decoction. This leaves decoction was evaporated in an oven at $50^{\circ} \mathrm{C}$ until a dry extract of weight Pf.

\section{Determination of Total Polyphenols}

The total polyphenol contents are determined according to the Folin-Ciocalteu colorimetric method (Singleton et al., 1999; Heilerová et al., 2003) modified (Konan, 2010). Added to $1 \mathrm{~mL}$ of each extract diluted to $1 / 10$ with distilled water, $1.5 \mathrm{~mL}$ of $\mathrm{Na}_{2} \mathrm{CO}_{3}(17 \%, \mathrm{~m} / \mathrm{v})$ and $0.5 \mathrm{~mL}$ of FolinCiocalteu reagent $(0.5 \mathrm{~N})$. The whole mixture was incubated at $37^{\circ} \mathrm{C}$ for $30 \mathrm{~min}$ and the absorbance was read at $760 \mathrm{~nm}$ against a blank without extract taken as reference. The quantification of the total polyphenols was determined using a linear calibration line $(\mathrm{y}=0.0227 \mathrm{x}$ 0.0126 ) carried out by a standard extract (gallic acid) at different concentrations ( 0 to $1000 \mu \mathrm{g} / \mathrm{mL}$ ) under the same conditions as the sample. The results are expressed as micrograms of gallic acid equivalent per gram of dry matter ( $\mu \mathrm{g}$ GAE/ g DM) of the powdered plant.

The total polyphenols content ( $Q$ in $\mu \mathrm{g}$ GAE / g DM) was calculated using equation $\mathrm{X}$ :

$$
\begin{aligned}
& \mathrm{Q}=\frac{\mathrm{V} \times \mathrm{C} \times \mathrm{d}}{\mathrm{m}} \\
& \mathrm{V}=\text { final volume of the extract }(\mathrm{mL}) \\
& \mathrm{C}=\text { concentration of the extract }(\mu \mathrm{g} / \mathrm{mL}) \\
& \mathrm{d}=\text { dilution } \\
& \mathrm{m}: \text { mass of dry matter of hydrolyzed plant material }(\mathrm{g})
\end{aligned}
$$

\section{Determination of Total Flavonoids}

The determination of the total flavonoids was carried out according to the method of Hariri et al. (1991) modified. $2 \mathrm{~mL}$ of each extract were diluted $1 / 10$ th and mixed with $100 \mu \mathrm{L}$ of Neu's reagent. The absorbance was read at $404 \mathrm{~nm}$ and compared to that of quercetol used as a standard $(0.05 \mathrm{mg} / \mathrm{mL})$ and undergoing the same treatment as the extract. The percentage of total flavonoids is calculated in quercetol equivalent according to the following formula (equation 2):

$$
\begin{aligned}
& \mathrm{F}(\%)=\frac{0,05 \times \text { Aext }}{\mathrm{Aq}} \times \frac{100 \times \mathrm{d}}{\text { Cext }} \\
& \text { Aext }=\text { Absorption of the extract } \\
& \mathrm{Aq}=\text { Absorption of quercetol } \\
& \mathrm{Cext}=\text { Concentration of the extract }(\mathrm{mg} / \mathrm{mL}) \\
& \mathrm{d}=\text { dilution }
\end{aligned}
$$

\section{Method for Antioxidant Activity Assay}

DPPH radical-scavenging activity (DPPH test)

Principle

DPPH is characterized by its ability to produce stable free radicals. This stability is due to the delocalization of free electrons within the molecule. The presence of these DPPH radicals gives rise to a dark purple color in the solution. DPPH, a stable purple free radical, is reduced to a yellow-colored compound in the presence of anti-oxidant compounds. Reduction of DPPH radicals by an antioxidant leads to discoloration of the solution (Molyneux, 2004) The color change can be monitored spectrophotometrically at $517 \mathrm{~nm}$ and in this way the antioxidant potential of a substance or a plant extract can be determined (Molyneux, 2004; Popovici, 2010). 


\section{Procedure}

The in vitro anti-free radical activity of the extracts was measured by the 2,2'-diphenyl-1-picrylhydrazyl (DPPH) test according to the method of Parejo (Parejo et al., 2002) with some modifications. For the preparation, $2 \mathrm{~mL}$ of a methanolic solution of DPPH $(100 \mu \mathrm{M})$ was mixed with $1.5 \mathrm{~mL}$ of different dilutions of the extracts (from 0 to 400 $\mu \mathrm{g} / \mathrm{mL}$ ). A range of concentrations from 0 to $200 \mu \mathrm{g} / \mathrm{mL}$ for vitamin $\mathrm{C}$ was used as a reference. The resulting mixture was then stored in the dark and at room temperature for 30 minutes. Then, the absorbance was measured with a spectrophotometer at $517 \mathrm{~nm}$ against a control composed of $2 \mathrm{~mL}$ of the DPPH solution and 1.5 $\mathrm{mL}$ of the methanolic solution. The Percentage of inhibition (\% PI) was calculated according to the formula below:

$$
\mathrm{PI}=\frac{\mathrm{A}_{0}-\mathrm{A}_{1}}{\mathrm{~A}_{0}} \times 100
$$

$$
\begin{aligned}
& \mathrm{PI}=\text { Percentage of inhibition }(\%) \\
& \mathrm{A} 0=\text { absorbance of the DPPH solution in the absence } \\
& \text { of the extract (blank) } \\
& \mathrm{A} 1=\text { absorbance of the DPPH solution in the } \\
& \text { presence of the extract (test) }
\end{aligned}
$$

\section{Determination in vitro of the total antioxidant activity by FRAP method (FRAP test) \\ Principle}

The FRAP method is based on the reduction of the ferric ion $(\mathrm{Fe} 3+)$ to ferrous ion $(\mathrm{Fe} 2+)$. This method evaluates the reducing power of compounds ( $\mathrm{Ou}$ et al., 2001). The presence of reducing agents (HA) in plant extracts results in the reduction of the $\mathrm{Fe}^{3}+/$ ferricyanide complex to ferrous form. Therefore, $\mathrm{Fe}^{2}+$ can be evaluated by measuring and monitoring the increase in density of the cyan blue color in the reaction at $593 \mathrm{~nm}$ (Chung et al., 2002). This method measures the reducing power of antioxidants present in a mixture by their ability to reduce ferric tripyridyltriazine (Fe3 + -TPTZ) to ferrous ion (Fe2 +- TPTZ) in acidic $\mathrm{pH}$.

\section{Procedure}

The FRAP (Reducing Power of Iron) test was carried out according to the method described by Pulido (Pulido et al., 2000). A fresh solution of the FRAP reagent (10 mM) was prepared by mixing $2.5 \mathrm{~mL}$ of the TPTZ solution (10 $\mathrm{mM}$ 2,4,6-Tri (2-pyridyl) -1,3,5-triazine in $40 \mathrm{mM}$ of $\mathrm{HCl}$ ) with $2.5 \mathrm{~mL}$ of $\mathrm{FeCl}_{3} \cdot 6 \mathrm{H}_{2} \mathrm{O}(20 \mathrm{mM})$ and $25 \mathrm{~mL}$ of acetate buffer ( $300 \mathrm{mM}$ of sodium acetate, $\mathrm{pH}$ led to 3.6 by acetic acid). Then, $3500 \mu \mathrm{L}$ of the FRAP reagent was added to $140 \mu \mathrm{L}$ of the test compounds dissolved in a methanolic solution. After $30 \mathrm{~min}$ of incubation in the dark, the absorbance was read at $593 \mathrm{~nm}$. The Trolox was used as a dosage control. The reducing power values obtained for the extract tested at various decreasing concentrations of Trolox $(1,0.5,0.25,0.125,0.0625,0.031 \mathrm{mg} / \mathrm{mL})$ made it possible to draw a histogram.

\section{Results and Discussion}

Any substance with the ability to capture or neutralize free radicals is called an antioxidant (Dehpour et al., 2009). The antioxidant activity of the dry extract of the fruit decoction of $P$. nitida and the dried leaves of $H$. floribunda was evaluated by two methods of evaluation of the antioxidant power (DPPH and FRAP).

\section{Antioxidant Activity by DPPH Method}

The decoction has $\mathrm{IC}_{50}$ anti-free radical activity. The $\mathrm{IC}_{50}$ is the concentration of extracts or vitamin $\mathrm{C}$ (reference substance) responsible for $50 \%$ inhibition of DPPH radicals. It is determined from the calibration curve for vitamin $\mathrm{C}$.

The $\mathrm{IC}_{50}$ of fruit decoction of $P$. nitida was higher than that of $H$. floribunda leaf decoction with values of 104.30 $\pm 3.17 \mu \mathrm{g} / \mathrm{mL}$ and $41.73 \pm 0.29 \mu \mathrm{g} / \mathrm{mL}$, respectively (Figure 1). On the other hand, these values nevertheless remained lower than that of the reference substance (8.06 $\pm 0.09 \mu \mathrm{g} / \mathrm{mL}$ ). The results are shown in Table 1 .

Table 1. Antiradical activity of fruits decoction of P. nitida and leaves decoction of H. floribunda by the DPPH method

\begin{tabular}{l|ccc}
\hline & P. nitida & H. floribunda & Vitamine C \\
\hline $\mathrm{CI}_{50}(\mu \mathrm{g} / \mathrm{mL})$ & $104.30 \pm 3.17$ & $41.73 \pm 0.29$ & $8.06 \pm 0.09$ \\
\hline
\end{tabular}

An extract is more antioxidant if its $\mathrm{IC}_{50}$ is lower (Kafui et al., 2018). Thus, the results obtained with the DPPH test in our study showed that $H$. floribunda is more antioxidant than $P$. nitida, since $P$. nitida has a higher $\mathrm{IC}_{50}$ than that of $H$. floribunda, but that these plants are less antioxidant than the reference substance vitamin $\mathrm{C}$.

Our results are in agreement with the work of several authors. The results of the anti-free radical activity of methanolic extracts (of ten medicinal plants from the Ivorian pharmacopoeia) and of quercetin (reference molecule whose $\mathrm{IC}_{50}=2.00 \pm 0.288 \mu \mathrm{g} / \mathrm{mL}$ ) presented by Bidié (2011) showed two categories of plants. The first group comprises of plants with strong anti-free radical activity, in which their IC50s are between 2 and $10.5 \mu \mathrm{g} /$ $\mathrm{mL}$. They are: Mitragyna ciliata Aubrév. \& Pellegr. ( IC $_{50}$ $=10.5 \pm 0.288 \mu \mathrm{g} / \mathrm{mL}$ ), Trichilia prieuriana A.Juss. ( IC $_{50}$ $=7.5 \pm 0.288 \mu \mathrm{g} / \mathrm{mL}$ ), Distemonanthus benthamianus Baill. $\left(\mathrm{IC}_{50}=4.50 \pm 0.288 \mu \mathrm{g} / \mathrm{mL}\right.$ ) and Chrysophyllum perpulchrum Mildbr. ex Hutch. \& Dalziel $\left(\mathrm{IC}_{50}=4.00 \pm\right.$ $0.288 \mu \mathrm{g} / \mathrm{mL}$ ). The second category comprises of plants exhibiting weak anti-free radical activity. This is the case for: Millettia zechiana Harms $\left(\mathrm{IC}_{50}=96 \pm 0.577 \mu \mathrm{g} / \mathrm{mL}\right.$ ), Ageratum conyzoides (L.) L. (IC50 $=76 \pm 0.577 \mu \mathrm{g} / \mathrm{mL}$ ), Parquetina nigrescens (Afzel.) Bullock $\left(\mathrm{IC}_{50}=75.5 \pm\right.$ $0.166 \mu \mathrm{g} / \mathrm{mL}$ ) and Sherbournia bignoniiflora (Welw.) Hua $\left(\mathrm{IC}_{50}=49.5 \pm 0.288 \mu \mathrm{g} / \mathrm{mL}\right)$. Compounds with an $\mathrm{IC}_{50}$ greater than $100 \mu \mathrm{g} / \mathrm{mL}$ do not have a significant antifree radical activity. They are: Desmodium gangeticum (L.) DC. $\left(\mathrm{IC}_{50}=10,000 \pm 288.7 \mu \mathrm{g} / \mathrm{mL}\right)$ and Blighia sapida K.D.Koenig $\left(\mathrm{IC}_{50}=17,000 \pm 577.4 \mu \mathrm{g} / \mathrm{mL}\right)$. Going by this hypothesis, the antioxidant activity of $P$. nitida would therefore be low because its $\mathrm{IC}_{50}$ was $104.30 \pm 3.17 \mu \mathrm{g} /$ $\mathrm{mL}$.

Koffi et al. (2018) showed, during their study on the antioxidant activity of some plants used in the region of Tiassalé (Côte d'Ivoire) in maintaining skin health, that out of a total of 30 extracts evaluated for their antioxidant power with DPPH anti-free radical test, seven including five methanolic extracts and two aqueous showed a percentage of inhibition superimposed on that of vitamin $\mathrm{C}$ $(95.79 \pm 10.53 \%)$. However, the methanolic extracts of 
Cajanus cajan (L.) Millsp. (95.71 $\pm 9.67 \%)$, of Cyathula prostrata (L.) Blume $(94.91 \pm 7.04 \%)$, of Eleusine indica (L.) Gaertn. (93.54 $\pm 10.21 \%)$ gave the strongest activities. Elaeis guineensis Jacq. (89.02 $\pm 12.76 \%)$, and Anchomanes difformis (Blume) Engl. (87.19 $\pm 10.54 \%)$ had intermediate activities. The IC50s are between 27.20 and $60 \mu \mathrm{g} / \mathrm{mL}$. These extracts are therefore less active than Vitamin C $(8.34 \mu \mathrm{g} / \mathrm{mL})$. These results suggest that the aqueous and methanolic extracts concentrate the most chemical constituents and possess the ability to donate hydrogen to a free radical. This trapping helps to sweep away the potential damage caused by free radicals (Wong et al., 2006; Chang et al., 2012). They are in fact a complex mixture of organic acids, amino acids and sugars which can also contribute to the sequestration of electrically charged free radicals (Wong et al., 2006; Chang et al., 2012).

Table 2. Antiradical activity of the fruit's decoction of $P$. nitida and the leaves decoction of $H$. floribunda by the FRAP method

\begin{tabular}{l|ll}
\hline & P. nitida & H. floribunda \\
\hline$\mu \mathrm{Mol}$ Eq trolox/g ES & $261,4 \pm 36,87$ & $365 \pm 20,36$ \\
\hline
\end{tabular}

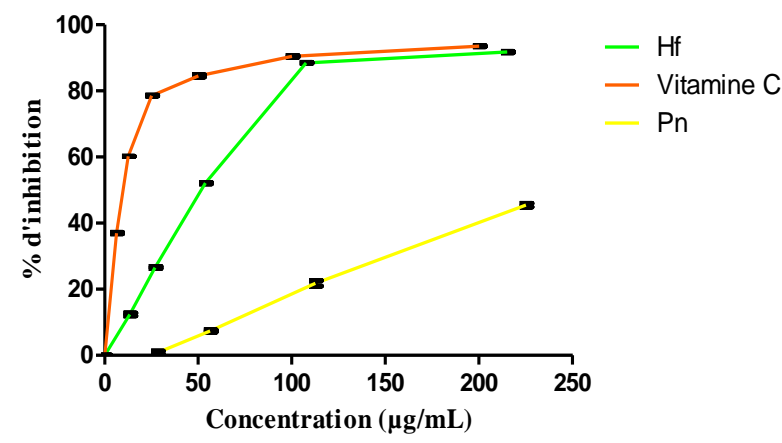

Figure 1. Percentage inhibition of the DPPH radical of the fruit decoction of P. nitida and the leaf decoction of $H$. floribunda compared to vitamin C

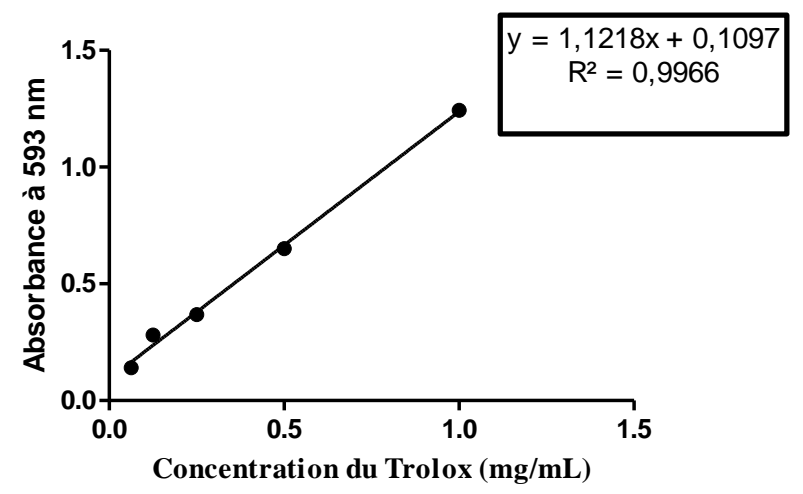

Figure 2. Calibration line for Trolox (P. nitida and $H$. floribunda)

According to the results obtained by Bougandoura and Bendimerad (2012) during their study on the evaluation of the antioxidant activity of aqueous and methanolic extracts of Satureja calamintha (L.) Scheele, the aqueous and methanolic extracts are endowed with moderate antioxidant power, their respective $\mathrm{IC}_{50}$ being 1.876 and 2.075. However, this $\mathrm{IC}_{50}$ was relatively lower than that of ascorbic acid used as a standard, which was in the order of
$0.134 \mathrm{mg} / \mathrm{mL}$. Antioxidant molecules such as ascorbic acid, tocopherol, flavonoids and tannins have been shown to reduce and decolorize DPPH due to their ability to release hydrogen (De Pooter and Schamp, 1986). The polyphenols contained in extracts of $S$. calamintha are probably responsible for these authors, for the antioxidant activity of these extracts.

Hatano et al. (1989), Duh et al. (1999) and N'guessan et al. (2007) showed the existence of a correlation between total phenol content and anti-free radical activity. According to Zhi and Ho (1995), the functional groups present in phenolic compounds in general can easily give up an electron or a proton to neutralize free radicals. The antioxidant activity of the two plants is therefore linked to their high total phenol content of $15,235.632 \pm 622 \mu \mathrm{g}$ GAE / g dry matter and 68,597.701 $\pm 3171 \mu \mathrm{g}$ GAE / g dry matter respectively for $P$. nitida and $H$. floribunda. Konan (2010) also demonstrated that plants which have good antioxidant activity contain high levels of phenolic groups. However, in addition to their high total phenol content, $P$. nitida and $H$. floribunda also contain total flavonoids according to phytochemical screening at values of $2.387 \pm$ $0.387 \%$ and $17.581 \pm 0.379 \%$ for $P$. nitida and $H$. floribunda respectively, which flavonoids are metabolites which express good antioxidant activity (N'guessan et al., 2007; Syamsudin et al., 2008).

\section{Antioxidant Activity Evaluation by FRAP Method}

The FRAP method was used in order to confirm the results obtained by the DPPH method. The linear regression curve of the reference antioxidant (vitamin $\mathrm{C}$ ) used as a standard is also shown in Figure 2. The fruits decoction of $P$. nitida showed an antioxidant activity value of $261.4 \pm 36.87 . \mu \mathrm{Mol} \mathrm{Eq}$ trolox / $\mathrm{g} \mathrm{ES}$, value lower than that of the decoction of the leaves of H. floribunda whose antioxidant activity value was $365 \pm 20.36 \mu \mathrm{Mol}$ Eq trolox / g ES (Table II).

The FRAP method is a method for measuring the capacity of analyzed samples, to reduce the ferric ion $\mathrm{Fe}^{3}$ + to the ferrous ion $\mathrm{Fe}^{2}+$ which is one of the antioxidant mechanisms. It is an easy, fast and reproducible technique (Karagôzler et al., 2008).

The reducing power, evaluated by the FRAP method in our study, showed that the antioxidant activity of $H$. floribunda was higher compared to that of $P$. nitida. This result confirms the presence of the antioxidant activity that we observed for the DPPH method.

Also, many researchers found that the reducing capacity of a compound can be considered as a significant indicator of its potential antioxidant activity (Bentabet et al., 2014). There is a link between the phenolic compounds content and the reducing power (Yildirim et al., 2001). The presence of polyphenols in the fruit and leaf decoctions of the two plants could therefore explain their antioxidant activity potential. However, the antioxidant activity of the decoction of $P$. nitida would be less compared to that of the decoction of $H$. floribunda, since the phenolic compound contents was respectively $39.19 \pm 4.37 \mathrm{mg}$ GAE / dry extract and $105.7 \pm 0.89 \mathrm{mg} \mathrm{GAE} /$ dry extract for each of the two plants.

Our results are in agreement with those of the literature. Indeed, the work carried out by Kafui Kpegba et al. (2018) reported that the $H$. floribunda plant possesses antioxidant activity with a value of $1009.9 \pm 0.6 \mu \mathrm{mol} \mathrm{Fe} 2+$ equivalent / $\mathrm{g}$. 
Bakchiche and Gherib (2014) worked on the determination of the antioxidant activities of polyphenols extracted from medicinal plants and they evaluated this antioxidant activity in vitro in three different ways: the DPPH test, the ABTS cation radical discoloration technique and the reducing power measurement. For this last test, the results obtained showed that the extracts exhibited high absorbances compared to the negative control. The two extracts of Arbutus unedo L. (0.001 \pm $0.006 \mathrm{mg} / \mathrm{mL}$ ) and Ziziphus lotus (L.) Lam. (0.001 \pm 0.006 $\mathrm{mg} / \mathrm{mL}$ ) are the most active among the extracts tested followed respectively by Anthemis arvensis L. extracts $(0.017 \pm 0.006 \mathrm{mg} / \mathrm{mL})$, Haloxylon scoparium Pomel $(0.002 \pm 0.006 \mathrm{mg} / \mathrm{mL})$ and Thymus algeriensis Boiss. \& Reut. $(0.025 \pm 0.006 \mathrm{mg} / \mathrm{mL})$; however, these activities remained significantly identical to that of ascorbic acid used as a positive control.

The antioxidant activity of methanolic and aqueous extracts of $S$. calamintha was evaluated by Bougandoura and Bendimerad (2012) using the FRAP method. They found that the reducing power of plant extracts is dose dependent (concentration dependent). At a concentration of $2.5 \mathrm{mg} /$ $\mathrm{mL}$, the reducing power of the methanolic extract of $S$. calamintha (at $700 \mathrm{~nm}$ ) is much greater (Optical Density = 0.484) compared to the aqueous extract (Optical Density = 0.097 ), but significantly lower than that of ascorbic acid (Optical Density $=11.98)$. The reducing power of the $S$. calamintha species is probably due to the presence of hydroxyl group in phenolic compounds which can serve as electron donor. Therefore, antioxidants are considered to be reducers and inactivators of oxidants (Iddhuraju and Becker, 2007). Some previous studies have also shown that the reducing power of a compound can serve as a significant indicator of its antioxidant activity potential (Jeong et al., 2004; Kumaran and Karunakaran, 2007).

Plants used in the treatment of chronic pathologies generally have good antioxidant activity combating the oxidative stress at the origin of these pathologies (Pan et al., 2008). There is also a strong correlation between antioxidant activity and the nature and content of the chemical groups present in the extract.

The presence of polyphenols in the fruits and leaves decoctions of these two plants could be responsible for this activity. Our results are in agreement with those of the literature. Indeed, the work carried out by Erharuyi et al. (2014) indicated that the plant has several pharmacological activities including antimalarial, anti-inflammatory, analgesic, antidiabetic, antimicrobial, antioxidant and antiulcer activities.

\section{Conclusion}

The present study proposed to carry out a comparative study of the antioxidant activity of the decoction of the fruits of $P$. nitida and the leaves of $H$. floribunda, two plants used in the traditional Ivorian medicine. The results indicated that the antioxidant activity of $H$. floribunda is higher than that of $P$. nitida. This study also confirms a certain correlation between phenolic compounds content and anti-free radical activity and between phenolic compounds and the reducing power of the ferric ion $(\mathrm{Fe} 3$ $+)$ to ferrous ion $(\mathrm{Fe} 2+)$. The results of various scientific researchers have so far revealed that the antioxidant potential of these plants could be used in the treatment and prevention of metabolic diseases. However, further studies on pure extracts and compounds of these species are needed to characterize the molecules responsible for this antioxidant activity.

\section{References}

Athamena S. 2009. Etude quantitative et évaluation de l'activité biologique des flavonoïdes des graines de Cuminum cyminum et des feuilles de Rosmarinus officinalis Mémoire magister, Université El-Hadj Lakhdar-Batna.

Atmani A, Chaher N, Atmani D, Berboucha M, Debbache N, Boudaoud H. 2009. Flavonoids in human health: from structure to biological activity. Current Nutrition and Food Science, 5(4): 225-237.

Bakchiche B, Gherib A. 2014. Activités antioxydantes des polyphenols extraits de plantes médicinales de la pharmacopée traditionnelle d'Algérie. International Journal of Innovation and Applied Studies, 9(1): 167-172.

Bentabet N, Boucherit-Otmani Z, Boucherit K. 2014. Composition chimique et activité antioxydante d'extraits organiques des racines de Fredolia aretioides de la région de Béchar en Algérie. Phytothérapie, 12: 364-371.

Bidié AP, N'guessan BB, Yapo AF, N'guessan JD, Djaman AJ. 2011. Activités antioxydantes de dix plantes medicinales de la pharmacopée ivoirienne. Sciences and Nature, 8(1): 1 - 11.

Chang CJ, Tzeng TF, Liou SS, Chang YS, Liu IM. 2012. Acute and 28-Day Subchronic Oral Toxicity of an Ethanol Extract of Zingiber zerumbet (L.) Smith in Rodents. Evidence-Based Complementary and Alternative Medicine, (10): 2 -11.

Chen CW, Ho CT. 1995. Antioxidant properties of polyphenols extracted from green tea and black tea. J Lipids, 2: 35-46.

Chung YC, Chang CT, Chao WW, Lin CF, Chou ST. 2002. Antioxidative activity and safety of the $50 \%$ ethanolic extract from red bean fermented by Bacillus subtilis IMR-NK1. Journal of Agricultural and Food Chemistry, 50: 2454-2458.

De Pooter HL, Schamp N. 1986. Comparaison of the volatils composition of some Calamintha satureja species. In: Progress in essential oil research. Ed. E-J. Brunk, Walter De Gruyter, Berlin, 139-150.

Dehpour AA, Ebrahimzadeh MA, Nabavi SF, Nabavi SM. 2009. Antioxidant activity of methanol extract of Ferula assafoetida and its essential oil composition. Grasas y Aceites, 60: 405-412.

Duh PD, Tu YY, Yen GC. 1999. Antioxydant activity of water extract of harng Jyur (Chrysanthemum morifolium Ramat). Lebensm.wiss. Technol, 32: 269-277.

Erharuyi O, Engel-Lutz N, Ahomafor J, Imieje V, Falodun A, Nebe B, Langer P. 2014. Anticancer activity of five forest crops used in African folklore antiproliferative and pro-apoptotic effects, Natural Product Research: Formerly Natural Product Letters, 28(10): 740-745.

Hariri EB, Sallé G, Andary C. 1991. Involvement of flavonoids in the resistance of two poplar cultivars to mistletoe (Viscum album L.). Protoplasma, 162(1): 20-26.

Hatano T, Edamatsu R, Hiramatsu M, Mori A, Fujita Y, Yasuhara T, Yoshida T, Okuda T. 1989. Effect of interaction of tannins with co-existing substances VI. Effect of tannins and related polyphenols on superoxyde anion radical and on DPPH radical. Chem. Pharm. Bull., 37: 2016-2021.

Heilerová L, Bućkova M, Tarapćik P, Silhár S, Labuda J. 2003. Comparison of antioxydative activity data for aqueous extracts of Lemon balm (Melissa officinalis L.), Oregano (Origanum vulgare L.), Thyme (Thymus vulgaris L.), and Agrimony (Agrimonia eupatoria L.) obtained by conventional methods and the DNA-based biosensor. Czech Journal Food Science, 21(2): 78-84.

Iddhuraju P, Becker K. 2007. The antioxidant and free radical scavenging activities of processed cowpea (Vigna unguiculata (L.) Walp.) seed extracts. Food Chemistry, 101(1): 10-19. 
Jeong SM, Kim SY, Kim DR, Jo SC, Nam KC, Ahn DU, Lee SC. 2004. Effects of heat treatment on the antioxidant activity of extracts from citrus peels. Journal of Agriculture and Food Chemistry, 52: 3389-3393.

Kafui K, Etonam TK, Oudjaniyobi S, Komlatsè T, Pakoupati B, Outéndé T, Nagba YG, Amegnona A, Messanvi G. 2018. A significant antihypertensive effect of Holarrhena floribunda supported by an exploratory phytochemical study. J. Herbmed Pharmacol, 7(3): 160-167.

Karagôzler A, Erdag CS, Çalmaz Emek Y. 2008. Antioxydant activity and proline content of leaf extracts from Dorystoechas hastate. Food Chemistry, 111(2) : 400-407.

Koechlin-RC. 2006. Oxygène, stress oxydant et supplémentations antioxydantes ou un aspect différent de la nutrition dans les maladies respiratoires. Nutrition Clinique et Métabolisme, 20(4):165-77.

Koffi AG, Ahoua ARC, Ekou L, Ekou T, Koné MW. 2018. Activité antioxydante de quelques plantes utilisées dans la région de Tiassalé (Côte d'Ivoire) dans le maintien de la santé de la peau. European Scientific Journal, 14(30) : 338-352.

Konan K. 2010. Etude chimique et évaluation de l'activité antioxydante de quatre plantes médicinales de Côte d'Ivoire. Thèse unique de Doctorat. Université d'Abobo-Adjamé, Abidjan, Côte d'Ivoire.

Kumaran A, Karunakaran RJ. 2007. In vitro antioxidant activities of methanol extracts of five Phyllanthus species from India. Lebensmittel-Wissenschaft und Technologie, 40: 344-352.

Macheix JJ, Fleuriet A, Jay-Allemand C. 2005. Les composés phénoliques des végétaux. Un exemple de métabolites secondaires d'importance économiques. Lausanne, press polytechniques et universitaires romandes, 192p.

Molyneux P. 2004. The use of the stable free radical diphenylpicrylhydrazyl (DPPH) for estimating antioxidant activity. Songklanakarin J. Sci. Technol, 26(2): 211-219.

Mohammed FS, Akgul H, Sevindik M, Khaled BMT. 2018. Phenolic content and biological activities of Rhus coriaria var. zebaria. Fresenius Environmental Bulletin, 27(8): 5694 5702.

Mohammed FS, Pehlivan M, Sevindik M. 2019. Antioxidant, antibacterial and antifungal activities of different extracts of Silybum marianum collected from Duhok (Iraq). International Journal of Secondary Metabolite, 6(4): 317-322.

Mohammed FS, Şabik AE, Sevindik E, Pehlivan M, Sevindik M. 2020. Determination of Antioxidant and Oxidant Potentials of Thymbra spicata Collected from Duhok-Iraq. Turkish Journal of Agriculture-Food Science and Technology, 8(5): 1171-1173.

Mohammed FS, Kına E, Sevindik M, Dogan M, Pehlivan M. 2021. Datura stramonium (Solanaceae): Antioxidant and Antimicrobial Potentials. Turkish Journal of AgricultureFood Science and Technology, 9(4): 818-821.

N'guessan JD, Zirihi GN, Kra AKM, Kouakou K, Djaman AJ, Guede-Guina F. 2007. Free radical scavenging activity, flavonoid and phenolic contents of selected Ivoirian plants. IJONAS, 4: 425-429.
Ou B, Hampsch-Woodill M, Prior RL. 2001. Development and validation of an improved oxygen radical absorbance capacity assay using fluorescein as the fluorescent probe. Journal of agricultural and food chemistry, 49(10): 46194626.

Pan Y, Wang K, Huang S, Wang H, Mu X, He C, Ji X, Zhang J, Huang F. 2008. Antioxydant activity of microwave -assisted extract of longan (dimocarpus longan lour.) peel. Food chemistry, 106: 1264- 1270.

Parejo I, Viladomat F, Bastida J, Rosas-Romero A, Flerlage N, Burillo J, Codina C. 2002. Comparison between the radical scavenging activity and antioxidant activity of six distilled and nondistilled Mediterranean herbs and aromatic plants. Journal of Agricultural and Food Chemistry, 50(23): 68826890.

Pehlivan M, Mohammed FS, Sevindik M, Akgul H. 2018. Antioxidant and oxidant potential of Rosa canina. Eurasian Journal of Forest Science, 6(4): 22-25.

Popovici C, Saykova I, Tylkowski B. 2010. Evaluation de l'activité antioxydant des composés phénoliques par la réactivité avec le radical libre DPPH. Revue de génie industriel, 4: 131-887.

Pulido R, Bravo L, Saura-Calixto F. 2000. Antioxidant activity of dietary polyphenols as determined by a modified ferric reducing/antioxidant power assay. Journal of agricultural and food chemistry, 48(8): 3396-3402.

Sevindik M, Akgul H, Pehlivan M, Selamoglu Z. 2017. Determination of therapeutic potential of Mentha longifolia ssp. longifolia. Fresen Environ Bull, 26(7): 4757-4763.

Sevindik M. 2021. Phenolic content, Antioxidant and Antimicrobial potential of Melanoleuca melaleuca edible mushroom. Journal of Animal and Plant Sciences, 31(3): 824830 .

Singleton L, Ortofer R, Lamuela-Raventos RM. 1999. Analysis of total phenols and other oxidation substrates and antioxidants by means of Folin-Ciocalteu reagent. Packer L (ed) Methods in enzymology Orlando Academic Press, 299: $152-178$.

Syamsudin, Shirly K, Broto S. 2007. Screening of some extracts from Garcinia parvifolia Miq (Guttiferae) for antiplasmodial, antioxydant, cytotoxic and antibacterial activities. Asian J. Plant Sci, 6: 972-976.

Wong SP, Leong LP, William JH. 2006. Antioxidant activities of aqueous extracts of selected plants. Food Chemistry, 99(4): 775 -783.

Yildirim A, Mavi A, Kara AA. 2001. Determination of antioxidant and antimicrobial activities of Rumex crispus L. extracts. Journal Agricultural and Food Chemstry, 49: 40804089.

Zhi PR, Liang LZ, Yi ML. 2008. Evaluation of the Antioxydant Activity of Syzygium cumini Leaves. Molecules, 13: 25452556. 